Кравченко В.Г. ${ }^{1}$, Іщейкін К.С. ${ }^{1}$, Степаненко В.І. ${ }^{2}$, Попова І.Б. ${ }^{1}$

\title{
Реформування дерматовенерологічної галузі і шляхи налаштування інтегративних відносин з первинною ланкою охорони здоров'я
}

\author{
${ }^{1}$ Українська медична стоматологічна академія, м. Полтава, Україна \\ ${ }^{2}$ Національний медичний університет імені О.О. Богомольця, м. Київ, Україна \\ vladkrav38@gmail.com,dvk2@ukr.net,churzo@i.ua
}

\author{
${ }^{1}$ Кравченко В.Г., ${ }^{1}$ Ищейкин К.Е., \\ ${ }^{2}$ Степаненко В.И., ${ }^{1}$ Попова І.Б. \\ Реформирование дерматовенерологической отрасли \\ и пути налаживания интеграционных отношений \\ с первичным звеном здравоохранения \\ ${ }^{1}$ Украинская медицинская стоматологическая академия, \\ г. Полтава, Украина \\ ${ }^{2}$ Национальный медицинский университет \\ имени О.О. Богомольца, г. Киев, Украина
}

${ }^{1}$ Kravchenko V.G., ${ }^{1}$ Ischeykin K.E., ${ }^{2}$ Stepanenko V.I., ${ }^{1}$ Popova I.B.

Reforming of the dermatovenological service and the ways of the settling of integrative relations with the primary health care

${ }^{1}$ Ukrainian Medical Stomatological Academy, Poltava

${ }^{2}$ National Medical University O.O. Bogomolets, Kyiv

\section{Вступ}

Реалізацією Закону України «Про реформування охорони здоров'я» 301.04 .2020 р. передбачено старт програми медичних гарантій 3 поширенням медичної допомоги на всіх рівнях організації, зокрема, на первинному i вторинному. В цих умовах постає актуальною виважена і чітка координація організаційних нововведень, раціональний розподіл і оптимізована інтеграція повноважень дерматовенерологічної служби із лікарями первинної медичної ланки.

Боротьба із сексуально-трансмісивними хворобами або інфекціями, що передаються статевим шляхом (ІПСШ), становлять на сьогодні реальну загрозу у світі, оскільки вони належать до соціально-небезпечних для здоров'я хворих і впливом на нащадків, а також широкою розповсюдженістю, в тому числі у високорозвинених країнах Свропи i Америки [1]. Навіть нестримний наступ ВIЛ/СНIД та TORCH-інфекції (хламідійної, трихомонадної, мікоплазмової, герпетичної) в останні часи не зменшив уваги органів охорони здоров'я до сифілітичної патології, її епідеміологічної підступності і важких наслідків. Упродовж багатьох десятиліть сифіліс був i залишається головним маркером i люстратором венерологічної напруженості в світі, небезпечність якого $\epsilon$ не тільки одним із показників рівня охорони здоров'я країн, а і завжди визнавався моральним тягарем будьякого суспільства. Динаміка захворюваності на сифіліс представлена на рисунку. Таким чином, епідеміологічна ситуація в Україні після чергового епідемічного спалаху наразі відзначається поступовим зниженням рівня захворюваності на сифіліс - реєстрація хворих в 2017 році зменшилася у порівнянні з 2000 роком у 14 разів, хоча показники все ще залишаються вище бажаних [2,3]. Проте, офіційні статистичні дані жодним чином не відображають реальний стан захворюваності та інфікованості населення на ІПСШ. Реєстрація сифілісу, зокрема, за різними оцінками, здійснюється лише від 10 до $40 \%$ реальної кількості випадків сифілісу $[4,6,8]$. Підтвердженням цього висновку $\epsilon$ так зване «зниження» захворюваності на гонорею і іншу урогенітальну венеричну інфекцію [7].

Нереалістичне «зниження» рівня захворюваності на сифіліс, гонорею і інші урогенітальні інфекції пов'язане, крім інших причин, з порушеннями в реєстрації пацієнтів, в тому числі структурами, які не контролюються органами та закладами охорони здоров’я (лікарі приватної практики і т.п.) $[2,3]$.

Сьогодні сифіліс, як i раніше, залишається своєрідним індикатором венеризму i глобальною проблемою у світі, оскільки число щорічно виявлених нових випадків захворювань неухильно збільшується. За прогнозами аналітичної кампанії «GlobalData», протягом наступного десятиліття число вперше виявлених випадків зараження сифілісом в США, Європі і інших країнах азійського і американського континенту буде сукупно збільшуватися щорічно із середньорічним темпом приросту (CAGR) 2,32\% і до 2027 р. досягне 1,2 млн.

B нашій країні на сучасному етапі відзначається нестабільна ситуація не тільки із захворюваністю на ІПСШ та інфекційно-заразні, а і на неінфекційні хвороби шкіри (псоріаз, алергійні дерматози, атопічний дерматит і ін.). На високому рівні перебуває захворюваність на дерматофітози (мікроспорію і ін.), коросту, інфекційні хвороби шкіри $[9,11]$ (таблиця). 


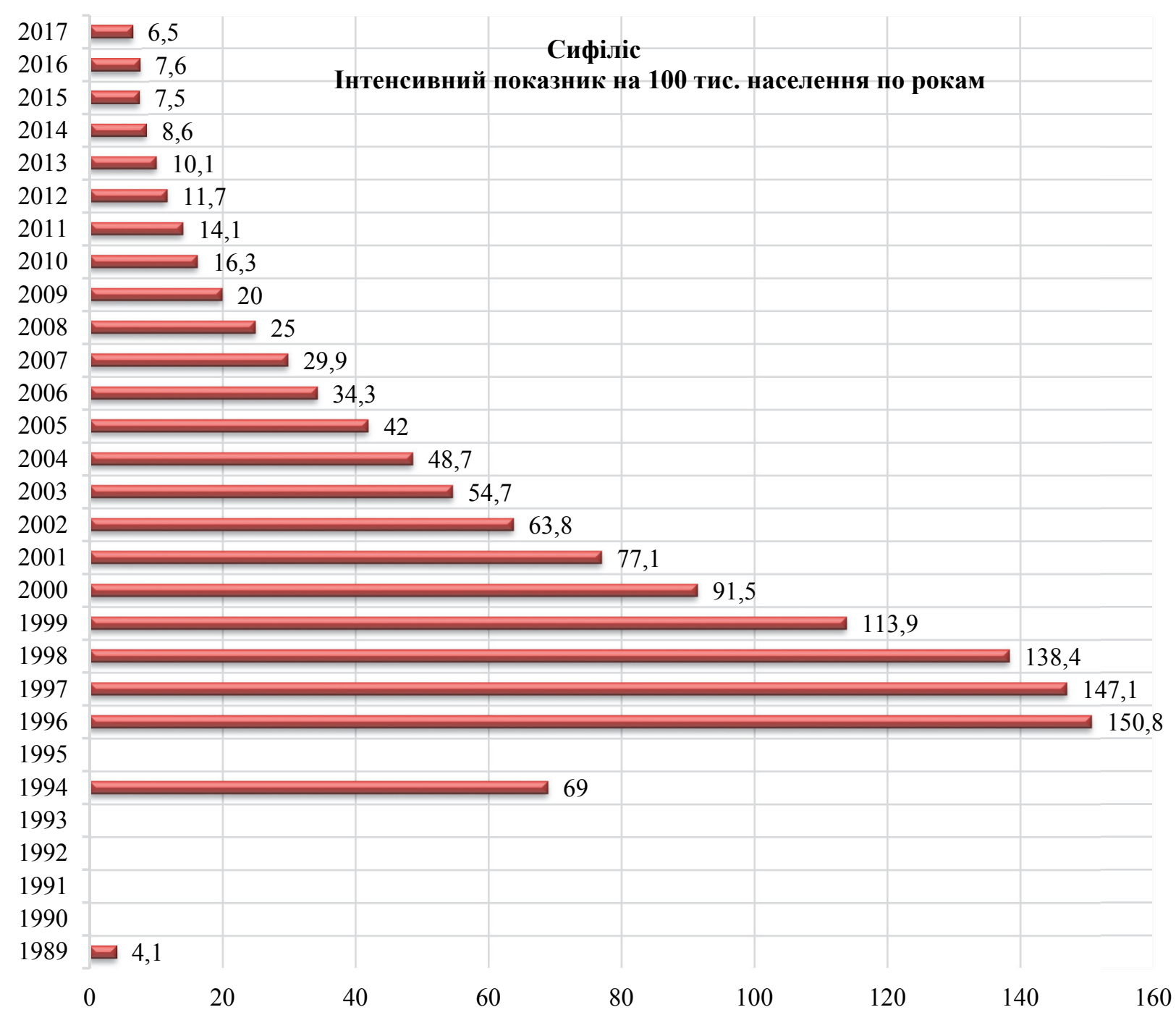

Рис. Динаміка захворюваності на сифіліс в Україні за період 1989-2017 pp.

(за даними Кравченка В.Г., Степаненка В.I., 2018) [3]

Таблиця. Структура захворюваності на дерматози з вперше в житті встановленим діагнозом в Україні в 2007-2017 рр. (за Я.Ф. Кутасевич, В.М. Волкославською, 2019) [9]

\begin{tabular}{|c|c|c|c|c|c|c|c|c|}
\hline & \multicolumn{2}{|c|}{2007} & \multicolumn{2}{|c|}{2014} & \multicolumn{2}{|c|}{2016} & \multicolumn{2}{|c|}{2017} \\
\hline & $\begin{array}{c}\text { Інтенсивний } \\
\text { показник } \\
\text { на } 100 \text { тис. } \\
\text { населення }\end{array}$ & $\begin{array}{c}\text { Питома } \\
\text { вага } \\
(\%)\end{array}$ & $\begin{array}{c}\text { Інтенсивний } \\
\text { показник } \\
\text { на } 100 \text { тис. } \\
\text { населення }\end{array}$ & $\begin{array}{c}\text { Питома } \\
\text { вага } \\
(\%)\end{array}$ & $\begin{array}{c}\text { Інтенсивний } \\
\text { показник } \\
\text { на } 100 \text { тис. } \\
\text { населення }\end{array}$ & $\begin{array}{c}\text { Питома } \\
\text { вага } \\
(\%)\end{array}$ & $\begin{array}{c}\text { Інтенсивний } \\
\text { показник } \\
\text { на } 100 \text { тис. } \\
\text { населення }\end{array}$ & $\begin{array}{c}\text { Питома } \\
\text { вага } \\
(\%)\end{array}$ \\
\hline Усього хворих & 4200,3 & - & 3659.6 & - & 3671.8 & - & 3688.4 & - \\
\hline Інфекції шкіри & 1467,8 & 34,9 & 1106,7 & 30,2 & 1067,4 & 29,1 & 1039,5 & 28,2 \\
\hline $\begin{array}{l}\text { Атопічний } \\
\text { дерматит }\end{array}$ & 82,5 & 1,96 & 86,5 & 2,4 & 86,7 & 2,4 & 89,8 & 2,43 \\
\hline $\begin{array}{l}\text { Контактний } \\
\text { дерматит }\end{array}$ & 700,3 & 16,7 & 653,3 & 17,9 & 674,2 & 18,4 & 687,1 & 18,63 \\
\hline Псоріаз & 29,7 & 0,71 & 31,5 & 0,86 & 28,8 & 0,78 & 30,0 & 0,81 \\
\hline Мікози стоп & 96,7 & 2,3 & 95,4 & 2,6 & 98,7 & 2,7 & 99,6 & 2,7 \\
\hline Дерматофітози & 32,0 & 0,77 & 41,2 & 1,13 & 45,7 & 1,2 & 49,8 & 1,35 \\
\hline Короста & 63,1 & 1,5 & 24,8 & 0,68 & 20,4 & 0,6 & 19,2 & 0,52 \\
\hline
\end{tabular}


Поглибленого аналізу захворюваності на інфекційні хвороби шкіри, зокрема, стрептостафілодерміти на теренах України провести не удається, оскільки офіційна реєстрація цієї патології у нас не передбачена. Не підлягають обов'язковій статистичній реєстрації, на жаль, численні хворі на хронічні рецидивуючі дерматози, які найчастіше потребують стаціонарної допомоги, супроводжуються великими втратами тимчасової непрацездатності хворих, або призводить до стійкої інвалідизації пацієнтів. Не маючи можливості орієнтуватися на офіційні статистикоінформаційні джерела, доводиться орієнтуватися на інформацію із наукових публікацій.

В період 2007-2017 рр. спостерігаються досить високі інтенсивні показники захворюваності на ряд широко розповсюджених дерматозів - (загалом 4200-3688 на 100 тис. населення). Цілком очевидно, що ці дані не відображають повністю реальних параметрів всієї дерматологічної патології на теренах України.

В окремому дослідженні ХНДІДіВ [10] приводяться дані захворюваності на дерматози серед дітей і підлітків за 11 років, згідно яких показник в цілому по Україні збільшився на $62,0 \%$, а поширеність хвороб шкіри та підшкірної жирової клітковини - на 5,4\%. Відзначається також зростання поширеності алергійних дерматозів, зокрема атопічного дерматиту(АД) на 69,7\%.

Суттєво зростає рівень захворюваності на псоріатичну хворобу, яка сьогодні $\epsilon$ не лише захворюванням, а і пожиттєвим станом. Питома вага псоріазу в загальній структурі захворюваності шкіри становить від 7 до 10\% [12,13,15]. За даними Міжнародної Федерації асоціацій псоріазу (International Federation of Psoriasis Associations) поширеність псоріазу у світі неоднакова і залежить від регіону, коливаючись в межах $1,2-5 \%$, а середній показник поширеності становить близько 3\% від загальної популяції. За даними ВООЗ, загальна кількість хворих на псоріаз в усьому світі сягає близько 125 млн осіб. Дві третини пацієнтів на псоріаз страждають легкими і помірними формами захворювання, а одна третина- середнім і важким ступенем. Найбільша розповсюдженість відзначається у Північній та Західній Європі, причому найвищі показники захворюваності на псоріаз із 18 країн світу виявлені у Німеччині (до 6,5\%), Нідерландах (до 5\%), Норвегії (до 4,8\%), Франції (до 4,7\%), Данії (до 4,2\%), де середній рівень поширеності сягає 2,8\%. Поширеність захворювання у Східній Азії набагато нижча (Китай - 0,05-1,23\%, Японія - 0,29-1,18\%), рідше на псоріаз хворіють представники монголоїдної раси, рідко- негроїдної, серед американських індіанців та ескімосів захворюваність на псоріаз практично не зустрічається [15]. Усереднені показники захворюваності на псоріаз в європейських країнах у осіб віком до 18 років складають близько 13\%. Загальний стан захворюваності на псоріаз в Україні наразі важко оцінувати із-за відсутності суворого обліку хворих i звітності дерматологічних закладів. Орієнтовні дані 3 цих питань, які зовсім не претендують на репрезентативність, можна отримати переважно із наукових джерел. За даними ХНДІДіВ в 2017 р. в Україні було зареєстровано 110155 хворих на псоріаз (що складає 259,7 на 100 тис. населення), тоді як у
2007 р. їх було 93713 (201,7 на 100 тис. населення). Уже навіть не повні дані свідчать про досить велику поширеність даного дерматозу в нашій країні. Важким ускладненням псоріазу $\epsilon$ артропатична форма (АП), поширеність якого становить від 2,0 до $29,6 \%$ і навіть більше третини від загального числа хворих на псоріаз [12,14-16]. В нашій країні стан проблеми псоріатичної хвороби 3 артропатичним ускладненням погіршується 3 кожним роком. Це зумовлюється недостатніми профілактичними заходами, спрямованими на раннє виявлення хворих, повільним впровадженням новітніх методів лікування псоріазу, недосконалою матеріальнотехнічною базою дерматологічних закладів, недостатнім охопленням санаторно-курортним лікуванням і санітарнопросвітницькою роботою серед населення [15].

Мета дослідження - аналітичне і організаційнометодичне визначення шляхів, механізмів та об'єму співпраці лікарів дерматовенерологів і лікарів первинної медичної ланки у спільній злагодженій роботі по наданню лікарських послуг при хворобах шкіри та інфекціях, що передаються статевим шляхом (ІПСШ).

\section{Результати дослідження та їх обговорення}

Боротьба із інфекціями, що передаються статевим шляхом (ІПСШ), інфекційними хворобами шкіри i підшкірної клітковини, хронічними і важкими інвалідизуючими дерматозами сьогодні представляється як комплексна проблема вітчизняної системи охорони здоров'я. Дерматовенерологічній службі в останні роки, попри недостатнє фінансування, вдається стримувати поширення гостро-заразних, паразитарних, хронічно рецидивуючих і важких та загрозливих для життя пацієнтів захворювань шкіри. Проте, висока захворюваність на сифіліс і венеричні урогенітальні інфекції, зростаюча поширеність інфекційних та неінфекційних дерматозів, особливо інвалідизуючих форм зобов'язує службу бути цілковито готовою до можливих епідеміологічних колізій.

В сучасних умовах ефективна діяльність дерматовенерологічної служби можлива лише за тісної співпраці із лікарями первинної ланки. Запобігання широкого розповсюдження заразно-шкірних хвороб i сифілітичної патології залежить в великій мірі від чітко окреслених рівнів і обсягів надання медичної допомоги пацієнтам лікарями сімейної медицини. Лікарі первинної ланки мають активно долучитися до роботи по ранньому і профілактичному виявленню корости, грибкових захворювань шкіри, заразних гноячкових хвороб, особливо у дітей дошкільного i шкільного віку 3 реєстрацією таких хворих. Лікарям сімейної медицини повинна бути властива добра підготовленість у питаннях візуальної (попередньої) діагностики розповсюдженої інфекційної патології (кір, короста, дерматофітози, шкарлатина, тиф, туберкульоз і ін.) і особливо сифілісу. Візуальне запідозрення інфекційних хвороб необхідне для оперативного скерування пацієнтів до спеціалізованого рівня, як це перебачається Настановами НСЗУ. Необхідність своєчасного виявлення інфекційних хвороб шкіри i ІПСШ належить до надважливих завдань первинної медичної ланки. У цьому відношенні постають 
деякі застереження. Вони стосуються, насамперед, заключної діагностики, як інфекційних i важких дерматозів, так і ІПСШ, яка повинна проводитися лише в спеціалізованих закладах, де є для цього необхідні умови. Недотримання існуючих стандартів діагностики може спричинити не тільки неадекватну терапію дерматозів, a i епідемічні спалахи інфекцій. Паціенти на хронічні дерматози можуть обслуговуватися лікарями сімейної медиини після встановлення діагнозу i проведення специфічного курсового лікування. Прерогативою лікарів сімейної ланки $\epsilon$ проведення підтримуючого, в тому числі кортикостероїдного лікування після «відтитрування» підтримуючої стероїдної дози.

Лікування пацієнтів із заразними хворобами шкіри повинно проводитися також лікарями-спеціалістами після лабораторного обстеження i 3'ясування етіологічного діагнозу. Тільки такий алгоритм здатний забезпечити максимальне запобігання розповсюдження заразних шкірних хвороб. Лікування хворих на псоріатичну хворобу і АД повинно забезпечуватися спеціалізованими закладами, в яких зосереджені необхідні кадрові, матеріальні ресурси і спеціальне медичне обладнання (бактеріологічні, біохімічні лабораторії, рентген-кабінети, лікарі високої кваліфікації, установки ПУВА-терапї̈, солярії тощо). Лікування пацієнтів на важкі і хронічнорецидивуючі дерматози на первинному рівні можливе в міжрецидивний період, як і контроль за виконанням пацієнтами плану підтримуючої терапії після лабораторно-інструментального підтвердження діагнозу і призначення спеціалістами відповідних лікувальних i профілактичних заходів. Лікування коморбідних станів тяжких форм псоріатичної хвороби (в тому числі артропатичний псоріаз), наприклад, в терапевтичному відділенні повинен бути можливим лише за направленням спеціалістів обласного дерматологічного закладу.

Діагностика i призначення специфічної терапії пацієнтам на ІПСШ повинні проводитися безумовно лише в умовах спеціалізованого закладу, де існують всі необхідні засоби і методи дослідження (сифілітичних шанкрів на бліду трепонему, мазків-зішкребів із уретри на урогенітальні інфекції, дослідження секрету простати на патогени, трепонемні і нетрепонемні серологічні тести, уретроскопічне дослідження i т.і.). Недотримання зазначених стандартів діагностики і лікування венеричних хвороб може стати причиною не тільки неадекватної терапії 3 непередбачуваними наслідками для здоров'я пацієнтів і нащадків, а і причиною епідеміологічних спалахів інфекцій. Проведення санітарно-просвітницької роботи по профілактиці ІПСШ і заразних шкірних хвороб $€$ одним із дієвих ресурсів співпраці сімейних лікарів 3 дерматовенерологами. Спільна діяльність дерматовенерологів i сімейних лікарів повинна проводитися максимально в інтересах пацієнтів і громадянського суспільства в цілому, оскільки заразні шкірні захворювання і ІПСШ є хворобами соціальними і загрозою епідеміологічного характеру. Така аргументована i переконлива позиція дерматовенерологічної служби, на наш погляд, повинна знайти підтримку у керівництва охорони здоров'я, як актуальна, аргументована і виправдана.

Вірогідна і можлива «гонитва» за збільшенням кількості обслужених пацієнтів була би у даному випадку вкрай некоректною і неприпустимою, здатною принести очевидну шкоду не тільки окремому паціенту, але i супільству.

\section{Висновки}

Організація надання спеціалізованої медичної допомоги хворим, безумовно, потребує налагодження i постійного зміцнення інтегративних зв'язків між лікарями дерматовенерологами i сімейної медицини. Для досягнення спільної мети лікарі первинної ланки мають долучитися до активної роботи, головним чином, в таких сферах: а) раннього виявлення захворювань на коросту, заразних інфекційних, грибкових захворювань шкіри, а також хронічно рецидивуючих і важких дерматозів та оперативного скерування пацієнтів на спеціалізований рівень; б) по обслуговуванню пацієнтів 3 тяжкими i хронічними дерматозами в міжрецидивний період, в) до контролю за виконанням пацієнтами плану підтримуючого лікування, в т.ч. стероїдними гормонами; г) проведення санітарно-просвітницької роботи, адже щоб боротися із соціальним злом, про нього треба говорити відверто і голосно!

Важливою складовою у готовності лікарів первинної ланки до успішної роботи 3 дерматовенерологами слід вважати запровадження обов'язкового циклу удосконалення на кафедрах шкірних та венеричних хвороб за спеціально розробленою програмою.

Реформування системи охорони здоров'я в Україні в цілому повинно відбуватися з урахуванням переконливого вітчизняного досвіду дермато-венерологічної служби. Кожній галузі медицини притаманні свої повноваження i обов'язки, але запорукою успіху можуть бути лише чітка інтеграція спільних обов'язків. Від раціонального вирішення цього питання залежить ефективність діяльності обох служб. Отриманий досвід спільної роботи може стати підгрунтям для розроблення та видання відповідної нормативно-регламентуючих матеріалів.

\section{Література}

1. Короленко В.В. Аналіз епідеміологічної ситуації щодо сифілісу в країнах Свропейського Союзу та Сполучених Штатах Америки як передумова створення системи державного управління соціально небезпечними інфекціями. - Укр. журнал дерматології, венерології, косметології, 2016, №2, с.98-104.

2. Адаптована клінічна настанова, заснована на доказах, Проект «Сифіліс» державного експертного центру МОЗ України, Київ, 2017. 
3. Кравченко В.Г., Степаненко В.І. Аналітичний огляд захворюваності на інфекції, що передаються статевим шляхом, у період 1945-2017pp. та можливі перспективні заходи щодо зниження їх поширеності в Україні. - Український журнал дерматології, венерології, косметології, 2018, №3, с.15-21.

4. Бондаренко Г.М., Унучко С.В., Губенко Т.В., Матюшенко В.П. Клініко-епідеміологічні особливості сифілісу на сучасному етапі. - Дерматологія та венерологія, 2014, № 2 (64), с.65-70.

5. Волкославская В.Н., Гутнев А.Л. О заболеваемости инфекциями, передающимися половым путем, в Украине. Клінічна імунологія. Алергологія. Інфектологія. Спец- випуск № 1, 2011. - С. 10-12.

6. Нізова Н.М. Актуальні питання розвитку системи громадського здоров'я в Україні. - Матеріали науковопрактичної конференції з міжнародною участю 24-25.05.17 р., м. Ужгород. Здоров’я нації, 2017, №3 (44), с.12-13.

7. Щорічні доповіді про стан здоров'я населення, санітарно-епідеміологічну ситуацію та результати діяльності системи охорони здоров'я України, 2013-2015 рр. - ДУ «Український інститут стратегічних досліджень МО3 України».

8. Інфекції, що передаються статевим шляхом (ІПСШ). - ДУ «Центр громадського здоров'я Міністерства охорони здоровя України». - Київ, 2017.

9. Кутасевич Я.Ф., Волкославська В.М. Стан ресурсів і діяльність дерматовенерологічної служби за 1998 2018 рр. в Україні. Нагальні задачі. - Дерматологія, венерологія, 2019, №2(84) с.46-49.

10. Волкославська В.М., Гутнєв О.Л. Про стан захворюваності та особливості перебігу деяких дерматозів у підлітків в Україні. - Дерматологія, венерологія, с.16-20.

11. Статистичні відомості інформаційно-аналітичного відділу Полтавської обл. ради, 2018.

12. Вантюх Н.В. Сучасні аспекти етіології та патогенезу псоріазу. - Науковий вісник Ужгородського університету, серія «Медицина», Ужгород, 2013, в. 1(46), с.182-187.

13. Смченко Я.О., Іщейкін К. С., Кайдашев І. П. Аналіз захворюваності та поширеності на псоріаз в Україні та в Полтавській області. - Вісник проблем біології і медицини, Полтава, 2014, том 14, Вип. 3(47), с.72-76.

14. Сизон О.О. Епідеміологія та взаємозалежність коморбідності артропатичного псоріазу і клінічного перебігу хвороби. - Український журнал дерматології, венерології, косметології, 2014, №1(52). С.14-24.

15. Котвіцька А.А., Карло В.В. Дослідження показників поширеності псоріазу в країнах світу та в Україні. Запорізький медичний журнал, 2013, №3(78), с.38-42.

16. Харченко Т. Псориаз в Украине: современные подходы к решению проблемы. - Український медичний часопис, 01.10.2012 p., www.umj.com.ua., c. 1-3.

\section{References}

1. Korolenko V.V. Analiz epidemiolohichnoi sytuatsii shchodo syfilisu v krainakh Yevropeiskoho Soiuzu ta Spoluchenykh Shtatakh Ameryky yak peredumova stvorennia systemy derzhavnoho upravlinnia sotsialno nebezpechnymy infektsiiamy. - Ukr.zhurnal dermatolohii, venerolohii, kosmetolohii, 2016, №2, s.98-104.

2. Adaptovana klinichna nastanova, zasnovana na dokazakh, Proekt «Syfilis» derzhavnoho ekspertnoho tsentru MOZ Ukrainy, Kyiv, 2017.

3. Kravchenko V.H., Stepanenko V.I. Analitychnyi ohliad zakhvoriuvanosti na infektsii, shcho peredaiutsia statevym shliakhom, u period 1945-2017 rr. ta mozhlyvi perspektyvni zakhody shchodo znyzhennia yikh poshyrenosti v Ukraini. Ukrainskyi zhurnal dermatolohii, venerolohii, kosmetolohii, 2018, №3, s.15-21.

4. Bondarenko H.M., Unuchko S.V., Hubenko T.V., Matiushenko V.P. Kliniko-epidemiolohichni osoblyvosti syfilisu na suchasnomu etapi. - Dermatolohiia ta venerolohiia, 2014№ 2 (64), s.65-70.

5. Volkoslavskaia V.N., Hutnev A.L. O zabolevaemosty ynfektsyiamy, peredaiushchymysia polovыm putem, v Ukrayne. Klinichna imunolohiia. Alerholohiia. Infektolohiia. Spets- vypusk № 1, 2011. - S. 10-12.

6. Nizova N.M. Aktualni pytannia rozvytku systemy hromadskoho zdorovia v Ukraini -Materialy naukovopraktychnoi konferentsii z mizhnarodnoiu uchastiu 24-25.05.17 r., m. Uzhhorod. Zdorovia natsii, 2017, №3 (44), s.12-13.

7. Shchorichni dopovidi pro stan zdorovia naselennia, sanitarno-epidemiolohichnu sytuatsiiu ta rezultaty diialnosti systemy okhorony zdorovia Ukrainy, 2013-2015 rr. - DU «Ukrainskyi instytut stratehichnykh doslidzhen MOZ Ukrainy».

8. Infektsii, shcho peredaiutsia statevym shliakhom (IPSSh). - DU «Tsentr hromadskoho zdorovia Ministerstva okhorony zdorovia Ukrainy», Kyiv, 2017.

9. Kutasevych Ya.F., Volkoslavska V.M. Stan resursiv i diialnist dermatovenerolohichnoi sluzhby za $1998-2018$ rr. v Ukraini. Nahalni zadachi. - Dermatolohiia, venerolohiia, 2019, №2(84) s.46-49.

10. Volkoslavska V.M., Hutniev O.L. Pro stan zakhvoriuvanosti ta osoblyvosti perebihu deiakykh dermatoziv u pidlitkiv v Ukraini. - Dermatolohiia,venerolohiia, s.16-20.

11. Statystychni vidomosti informatsiino-analitychnoho viddilu Poltavskoi obl. rady, 2018.

12. Vantiukh N.V.Suchasni aspekty etiolohii ta patohenezu psoriazu. - Naukovyi visnyk Uzhhorodskoho universytetu, seriia «Medytsyna», Uzhhorod, 2013, v. 1(46), s.182-187.

13. Iemchenko Ya.O., Ishcheikin K. Ye., Kaidashev I. P. Analiz zakhvoriuvanosti ta poshyrenosti na psoriaz v Ukraini ta v Poltavskii oblasti. - Visnyk problem biolohii i medytsyny, Poltava, 2014, tom 14, Vyp. 3(47), s.72-76.

14. Syzon O.O. Epidemiolohiia ta vzaiemozalezhnist komorbidnosti artropatychnoho psoriazu i klinichnoho perebihu khvoroby. - Ukrainskyi zhurnal dermatolohii, venerolohii, kosmetolohii, 2014, №1(52). S.14-24. 
15. Kotvitska A.A., Karlo V.V. Doslidzhennia pokaznykiv poshyrenosti psoriazu v krainakh svitu ta v Ukraini. Zaporizkyi medychnyi zhurnal, 2013, №3(78), s.38-42.

16. Kharchenko T. Psoryaz v Ukrayne: sovremennie podkhodi k reshenyiu problemi.-Ukrainskyi medychnyi chasopys, 01.10.2012 r., www.umj.com.ua., s. 1-3.

Дата надходження рукопису до редакції: 17.02.2020 p.

Мета дослідження - визначення механізмів та об’єму співпраці лікарів дерматовенерологів і лікарів первинної медичної ланки у спільній роботі по наданню лікарських послуг.

Матеріали - аналіз стану захворюваності на ІПСШ і дермальну патологію в Україні на основі багаторічного досвіду авторів.

Результати. Запропоновані алгоритм, об’єм і раціональні підходи до надання послуг пацієнтам на первинному і спеціалізованому рівні.

Висновки. Діагностика і лікування хворих на важкі і інфекційні дерматози, як і ІПСШ, повинні проводитись на спеціалізованому рівні. Перманентне спостереження за пацієнтами 3 хронічно-рецидивуючими і поширеними дерматозами в між рецидивні періоди покладається на лікарів сімейної медицини.

Ключові слова: дерматози, захворюваність, інфекції, ІПСШ, сімейна медицина.

Цель исследования - определение механизмов и объема сотрудничества врачей дерматовенерологов и врачей первичного медицинского звена в общей работе по оказанию врачебных услуг.

Материалы - анализ заболеваемости ИППП и дермальной патологии в Украине на основе многолетнего опыта авторов.

Результаты. Предложены алгоритм, объем и рациональные подходы к предоставлению услуг пациентам на первичном и специализированном уровне.

Выводы. Диагностика и лечение больных тяжелыми и инфекционные дерматозы, как и ИППП, должны проводиться на специализированном уровне. Перманентное наблюдение за пациентами с хронически-рецидивирующим и распространенными дерматозами в между рецидивные периоды возлагается на врачей семейной медицины.

Ключевые слова: дерматозы, заболеваемость, инфекции, ИППП, семейная медицина.

The aim of the study was to identify the pathways, mechanisms and scope of collaboration between dermatovenereologists and primary care physicians in working together to provide medical services

Materials are the analytical studies of STI disease and skin pathology in Ukraine and results of many years of experience of the organizational and methodological activity of the authors.

Results: the algorithm, scope and rational approaches of professional relations to the provision of services to patients of dermatovenerological profile at the primary and specialized level are offered, as well as clear integrative responsibilities of doctors of both levels, are outlined.

Conclusions. Diagnosis and treatment of patients with severe and infectious dermatoses, as well as STIs, should be performed at a specialized level. Permanent supervision of patients with chronic recurrent and widespread dermatoses in between recurrent periods relies on family medicine physicians.

Key words: dermatoses, morbidity, infections, STIs, family medicine

Конфлікт інтересів: відсутній.

Conflicts of interest: authors have no conflicts of interest to declare.

\section{Відомості про авторів}

Кравченко Володимир Григорович - д.м.н., професор кафедри шкірних та венеричних хвороб УМСА; м. Полтава. vladkrav38@gmail.com, ORCID0000-0001-5538-3991.

Іщейкін Костянтин Свгенович - д.м.н., професор, зав. кафедрою шкірних та венеричних хвороб УМСА; м. Полтава.

Степаненко Віктор Іванович - д.м.н., професор, зав. кафедри дерматовенерології НМУ ім. О.О. Богомольця; м. Київ. dvk2@ukr.net, ORCID 0000-0003-4710-1151.

Попова Ірина Борисівна - к.м.н., доцент кафедри шкірних та венеричних хвороб УМСА, головний лікар Полтавського ОК ШВД; м. Полтава. churzo@i.ua. 